DOI https://doi.org/10.18551/rjoas.2020-11.28

\title{
THE EFFECT OF SAFETY TRAINING AND WORKERS INVOLVEMENT ON SAFETY COMPLIANCE WITH SAFETY KNOWLEDGE AS A MEDIATION VARIABLES
}

\author{
Rizki Santi*, Wahyuni Purbudi, Sugandhini Dyah \\ Faculty of Economics and Business, Universitas Pembangunan Nasional Veteran \\ Yogyakarta, Indonesia \\ *E-mail: santirizky11@gmail.com
}

\begin{abstract}
This research aims to analyze the effect of safety training and workers involvement of the safety compliance workers at PT Powerindo Prima Perkasa with safety knowledge as mediating variables. The population in this research were all production section employees who worked at PT Powerindo Prima Perkasa. The sampling technique using the census method (saturated sample) with 183 respondents. The data analysis technique is using partial least square (PLS) with two models, namely the outer model and inner model. The findings showed that safety training positively relates to safety compliance, and workers involvement positively relates to safety compliance. Furthermore, safety knowledge mediating the relationships between safety training and workers involvement to safety compliance.
\end{abstract}

\section{KEY WORDS}

Safety training, workers involvement, safety knowledge, safety compliance.

In Indonesia, manufacturing companies play an important role in the country's economic growth. This is evident in 2018 the manufacturing industry sector is the largest contributor to gross domestic product (GDP) in the Asean region, besides that the industrial sector in Indonesia is also ranked fifth in the world. The positive impact of this increase is the opening of wide employment opportunities (Ministry of Industry, 2019). Besides that, the main problem that always arises in every work activity of the manufacturing industry is the emergence of occupational safety threats. One of the threats to work safety in a manufacturing work environment is the problem of work accidents.

According to some data obtained regarding the number of work accidents that occur in Indonesia, the Employment Social Security Administration (BPJS) recorded that in 2017 the number of work accidents was 123,041 cases, and in 2018 it was the highest accident rate in the last 28 years, namely 173,105 cases, an increase of around 29\% from 2017 (katigaku.Top) while Ida said that in 2018 there were 114,148 cases of accidents in the workplace and in 2019 there were 77,295 cases (Kemnaker.go.id).

Work safety hazards and risks cannot be avoided in every job. Therefore, control efforts are needed in order to reduce the losses that will occur as a result of these hazards and risks. One of the control measures that can be done is to increase the safety compliance of employees' work. Work accidents and injuries can be avoided if employees comply with safety standards, procedures and regulations in the workplace (Mearns et al., 2001; Dahl 2013). The behavior of employees who comply with safety is the most important thing that must be improved by every worker because human behavior at work can create risks related to safety (Pertiwi, 2016)

Based on a literature study on safety compliance, Subramaniam et al., (2016); Mashi et al., (2016); Kao et al., (2019); Vinodkumar and Bhasi (2010) state that efforts to improve safety compliance can be done in various ways, one of which is by providing safety training, involving workers in safety programs, and increasing employee safety knowledge. This study refers to previous research conducted by Vinodkumar and Bhasi (2010), but this study only uses mediation of safety knowledge. This study uses safety knowledge as a mediator between safety training and workers involvement in safety compliance. 
In addition, several research gaps were raised in this study. The first research gap is related to safety training to safety compliance. Previous research said that efforts to improve safety compliance were one of them by providing safety training, Mashi et al., (2016). Huang et al., (2012) and Cooper and Philips (2004) said that safety training can predict and improve safety behavior among manufacturing employees, and is a key factor in maintaining and changing workers' attitudes towards safety. However, Vinodkumar and Bhasi (2010) show that safety training to safety compliance does not have a strong relationship, where safety training alone is not able to increase safety compliance. This is confirmed by the research of Liu et al.,

The second research gap is related to safety knowledge to safety compliance. safety knowledge is an effort so that employees know how to perform tasks in a safe manner. Employees who have safety knowledge will be more aware of the consequences of their actions if they do not comply with work procedures. Jiang et al., (2010) show that employees with high safety knowledge can increase safety compliance. In addition, safety knowledge also allows workers to have safety-related instructions and demonstrate safety-related behavior (Burke \& Sarpy, 2003; Fabrigar et al., 2006). However, this study is not in line with the research conducted by Guo et al., (2015) stated that the fact that employees have knowledge of safety does not always make employees obey the safety regulations. Okeya et al., (2016) and Christian et al., (2009) also said that safety knowledge has a weak influence on safety compliance, but safety knowledge is able to be the strongest mediator to safety compliance (Vinodkumar and Bhasi, 2010; Neal et al. ., 2000).

This research was conducted before Indonesia was exposed to Covid-19. Apart from some of the phenomena above, based on observations and interviews conducted at PT Powerindo Prima Perkasa conducted by several workers which resulted in low safety compliance, this was due to the lack of employee behavior in complying with safety, such as not fully implementing regulations concerning safety and existing occupational health, does not comply with standard operating procedures (SOP), is not careful at work, is still careless at work, does not use personal protective equipment (PPE), so the impact of this noncompliance causes a high rate of work accidents that occur in the company .

According to the work accident report data at PT Powerindo Prima Perkasa it is known that it is still relatively high. It is known that in 2015 there were 18 cases of work accidents, in 2016 it increased to 21 cases, and in 2017 it increased significantly to 37 cases, while in 2018 it decreased to 26 cases. Based on the results of observations made at PT Powerindo Prima Perkasa, $98 \%$ of work accidents are experienced by production employees. These work accidents show that there is a tendency for low safety compliance so that safety compliance needs to be improved by increasing the safety knowledge of each employee. To be able to increase safety knowledge at PT Powerindo Prima Perkasa, it can be done by providing safety training and workers involvement in solving safety problems, besides that the aim of increasing safety knowledge is so that employees know better how to use personal protective equipment (PPE) correctly, knowing the type -types of occupational hazards, and knowing how to deal with risks when a work accident occurs. Thus, the objectives of this study are: 1) To analyze the effect of safety training on the safety compliance of employees at PT Powerindo Prima Perkasa. 2) To analyze the effect of workers involvement on the safety compliance of employees at PT Powerindo Prima Perkasa. 3) To analyze safety training on employee safety compliance with safety knowledge as a mediating variable at PT Powerindo Prima Perkasa. 4) To analyze workers involvement in employee safety compliance with safety knowledge as a mediating variable in PT Powerindo Prima Perkasa.

\section{LITERATURE REVIEW}

Safety compliance includes activities important to workplace safety such as following standard operating procedures and using appropriate personal protective equipment (Neal \& Griffin, 2006). Masia and Pienaar (2011) further define safety compliance, the extent to which employees comply with safety standards, procedures, requirements and legal obligations. 
Subramaniam et al., (2016); Mashi et al., (2016); Kao et al., (2019); Vinodkumar and Bhasi (2010) state that efforts to improve employee safety compliance can be done in various ways, one of which is by providing safety training, involving workers in safety programs, and increasing employee safety knowledge.

Safety training is a training program designed for employee safety (Vinodkumar and Bhasi, 2010). Safety training can be a means by which accidents can be predicted (Vredenburgh, 2002). The safety training program was built to improve workers' understanding, attitudes and knowledge. According to Vinodkumar and Bhasi (2010) and Rinehart (2015) safety training indicators, namely: 1) comprehensive safety training, 2) training to deal with emergency situations, 3) competent mentors, 4) appropriate materials and 5) interesting method. The purpose of safety training is to improve staff operational skills, hazard identification abilities, and to raise safety awareness so that employees attach importance to production safety. understand the hazards that exist in the workplace and have the ability to operate safely. In addition, it is hoped that these employees can perform optimally for the company (Fibriany and Oktaviani, 2019)

Subramaniam et al., (2016) worker involvement in safety is one component of safety management practices to increase safety compliance. Worker involvement can be used as an important tool to promote safety compliance among employees. Robbins and Judge (2008) define workers involvement as measuring the degree to which individuals psychologically side with their work and consider the level of performance achieved as a form of self-appreciation. According to Vinodkumar and Bhasi (2010) workers involvement is measured in 3 factors, namely: 1) involvement in the identification of safety problems,

Safety knowledge is employees' knowledge of safety practices and procedures (Vinodkumar and Bhasi, 2010). Safety knowledge is also used as an anticipation to reduce injury (Elkind, 1993; Runyan \& Runyan, 1991). Specifically safety knowledge enables workers to have safety related instructions and demonstrate safety related behavior (Burke \& Sarpy, 2003; Fabrigar et al., 2006). A person who has good safety knowledge and shares this knowledge with others will receive significant personal benefits such as increased selfesteem, increased competence, increased social affiliation, increased reputation and a stronger sense of organizational commitment (Rahab and Wahyuni, 2013). Vinodkumar and Bhasi (2010) say there are three indicators to measure safety knowledge, namely: 1) Knowledge of using safety equipment, 2) Knowledge of types of work hazards 3) Knowledge of emergency response.

\section{METHODS OF RESEARCH}

This research is a quantitative study using a survey method of respondents. The purpose of this study was to determine the direct and indirect effect of safety training, workers involvement on safety compliance with safety knowledge as the mediating variable. The population in this study were employees of the production division who worked at PT Powerindo Prima Perkasa, totaling 183 employees. Sampling in this study used a total sampling or census method, namely a sampling technique where the sample is the same as the population (Sugiyono, 2015). The data technique in this study used a list of questions or a questionnaire. The data analysis tool used in this study was SmartPLS.

\section{RESULTS AND DISCUSSION}

Based on the results of the research, the respondents who were the subjects or respondents of this study were all male as many as 183 people $(100 \%)$ with ages between 21 - 32 years as many as 123 people (67.2\%), aged 33 - 44 years as many as 49 people (26 , 8\%), and 11 people aged between 45 - 56 years (6\%). people (94.5\%), and S1 as many as 5 people $(2.7 \%)$, with a working period of between 2 - 11 years as many as 172 people (94\%), a work period of between 12 - 21 years as many as 7 people (3.8\%), and the working period between $22-30$ years as many as 4 people (2.2\%). 
All indicators of variable safety training (X), worker involvement (X2), safety compliance $(Y)$, safety knowledge (Z) are declared valid. According to Chin (1998) an indicator is stated to have good validity if the loading factor value is $\geq 0.70$, while the value of 0.5 to 0.6 can be maintained for a model that is still in the development stage. Apart from that, the results of the significance test with the t test showed that all values of $P<0.05$. Thus, all statement items can be declared valid. This result is also supported by the AVE value which all values above 0.5 , thus it can be stated that all variables are declared valid with convergent validity. All indicators of the variable safety training (X), worker involvement (X2), safety compliance $(Y)$, safety knowledge $(Z)$ indicate the value of composite reliability and Cronbach alpha above 0.70 , so that it has good reliability.

Table 1 - Results of the structural model or inner model testing

\begin{tabular}{|l|l|l|}
\hline Testing & Test results & Criteria \\
\hline $\begin{array}{l}\text { Coefficient of Determination (R square) } \\
\text { Safety knowledge (R12) }\end{array}$ & 0.544 & Moderate \\
Safety Compliance (R22) & 0.506 & \\
\hline $\mathrm{Q} 2$ predictive relevance & $77.5 \%$ & $\begin{array}{l}\text { Good, that means that the observed values have } \\
\text { been reconstructed well with predictive relevance }\end{array}$ \\
\hline $\mathrm{Q} 2=1-(1-\mathrm{R} 12)(1-\mathrm{R} 22)=0.775$ & & \\
\hline
\end{tabular}

The coefficient of determination (R2) shows that safety knowledge is influenced by safety training and workers involvement in the amount of $54.4 \%$ and the remaining $45.6 \%$ is influenced by other factors not included in the model. While safety compliance is influenced by safety knowledge, safety training and workers involvement by $50.6 \%$, the remaining $49.4 \%$ is influenced by other factors not included in the model.

Q-square predictive relevance (Q2) where safety compliance is influenced by safety knowledge, safety training and workers involvement by $77.5 \%$, which means that the observed values have been reconstructed well with predictive relevance.

Testing the acceptance of the hypothesis can be seen from the value of the t-statistic more than> 1.96. The limit for accepting the proposed hypothesis is $P$ Values (Sig. T) $\alpha=$ 0.05. Referring to Yamin (2011) P-value $<\alpha$, it is said to be significant. The results of the PLS 3.2.7 output found the bootstrapping value with a sample of 183 resulting in an estimated value and probability ( $p$-value) shown in the following figure:

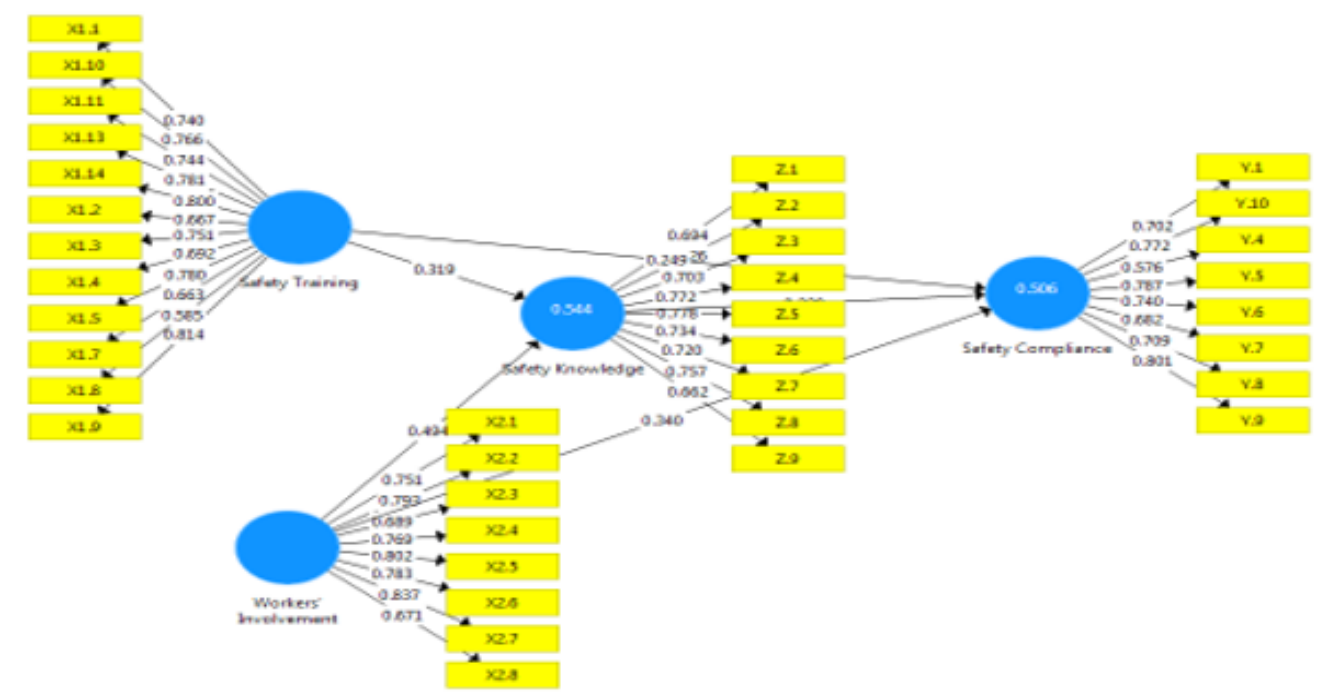

Figure 1. Hasil Uji Struktural Smartpls Model

The path analysis model stage is to explain the influence between variables with quantitative analysis as follows: 
Table 2 - Influence between variables with quantitative analysis

\begin{tabular}{|c|c|c|c|c|c|}
\hline $\mathrm{n} / \mathrm{n}$ & $\begin{array}{c}\text { Original } \\
\text { Sample }(O)\end{array}$ & $\begin{array}{l}\text { Sample Mean } \\
\text { (M) }\end{array}$ & $\begin{array}{l}\text { Standard } \\
\text { Deviation } \\
\text { (STDEV) }\end{array}$ & $\begin{array}{l}\text { T Statistics } \\
(\mid \text { O / STDEV |) }\end{array}$ & $\begin{array}{c}P \\
\text { Values }\end{array}$ \\
\hline Safety knowledge $\rightarrow$ safety compliance & 0.220 & 0.223 & 0.081 & 2,707 & 0.007 \\
\hline Safety training $\rightarrow$ Safety compliance & 0.249 & 0.258 & 0.067 & 3,723 & 0.000 \\
\hline Safety training $\rightarrow$ Safety compliance & 0.319 & 0.326 & 0.076 & 4,230 & 0.000 \\
\hline Workers involvement $\rightarrow$ Safety compliance & 0.340 & 0.336 & 0.089 & 3,813 & 0.000 \\
\hline Workers involvement $\rightarrow$ Safety knowledge & 0.494 & 0.491 & 0.089 & 5,564 & 0.000 \\
\hline Safety training $\rightarrow$ Safety Knowledge $\rightarrow$ Safety compliance & 0.070 & 0.073 & 0.023 & 2,206 & 0.028 \\
\hline $\begin{array}{l}\text { Workers involvement } \rightarrow \text { Safety Knowledge } \rightarrow \text { Safety } \\
\text { compliance }\end{array}$ & 0.109 & 0.109 & 0.046 & 2,367 & 0.018 \\
\hline
\end{tabular}

Effect of safety training and workers involvement on safety knowledge:

$$
\begin{gathered}
Z=P 1 X 1+P 2 X 2+e 1 \\
Z=0.319 X 1+0.494 X 2
\end{gathered}
$$

Effect of safety training, workers involvement and safety knowledge on safety compliance:

$$
\begin{gathered}
Y=P 3 X 1+P 4 X 2+P 5 Z+e 2 \\
Y=0.249 X 1+0.340 X 2+0.220 Z
\end{gathered}
$$

Based on this, it is known that the results of the first hypothesis testing show that safety training has a positive and significant effect on safety compliance as indicated by the $p$-value of $0.000 \leq 0.05$ and the t-value of $3.723 \geq 1.96$. safety training has an effect on safety compliance by $24.9 \%$. This is the menushow that the better safety training will increase safety compliance for employees of PT. Powerindo. This study is in accordance with the research of Subramaniam et al., (2016) who found that safety training has an effect on safety compliance. This is in line with research conducted by Mashi et al., (2016) who also said that by providing safety training, safety compliance will be high.

The result of testing the second hypothesis shows that workers involvement has a positive and significant effect on safety compliance, showing a path coefficient of 0.340 (positive) with a t-count value of 3.813 and a p-value of 0.000 . With a p-value of 0,000 which is smaller than the critical value $(\alpha=0.05)$, the positive effect of workers involvement on safety compliance is significant. The results of this study support previous research conducted by Mashi et al., (2016) in their research which states that worker involvement in safety has a positive and significant relationship to safety compliance. In addition, this study also states that worker involvement leads to a higher safety compliance behavior so that in developing a safety program the involvement of workers must be emphasized. In addition, Goetsch said (2011) when employees are involved in the design and implementation, monitoring and follow-up of the safety management process, they will have a sense of belonging to the program, which will ultimately lead to a reduction in the rate of accidents and injuries.

The results of testing the third hypothesis which states that safety training has a positive and significant effect on safety compliance with safety knowledge as mediation at PT Powerindo Prima Perkasa is supported. This is indicated by the p-value of $0.028<0.05$ and the t-value of $2.206 \geq 1.96$, which means that the research results show that safety training (X1) has an indirect and significant positive effect on employee safety compliance (Y) mediated by safety. knowledge (Z) at PT Powerindo Prima Perkasa. The resulting path coefficient from $X 1$ to $Y$ is 0.249 with a $p$ value $=0.000<0.05$. While the path coefficient mediated by $Z$ (safety knowledge) from $X 1 \rightarrow Z \rightarrow Y$ is 0.070 (positive) with a value of $p=$ $0.028<0.05$. The resulting weight of the indirect effect is positive and significant, so it means that the presence of $Z$ (safety knowledge) causes the effect of $X 1$ (safety training) on $Y$ (safety compliance) to increase. Conversely, when without $Z$ (safety knowledge) the effect of $\mathrm{X} 1$ (safety training) on $\mathrm{Y}$ (safety compliance) decreases. This shows that $\mathrm{Z}$ mediates $\mathrm{X} 1$ against $Y$. 
The results of this study support Bunner et al., (2018) who say that safety knowledge mediates the relationship between safety training and safety compliance. Safety training is one of the factors that influence safety knowledge, because it will be supported by efforts to convey safety information properly, with the firmness to apply safety rules and procedures, so it can increase safety knowledge where employee knowledge of safety practices and procedures will increase., which in turn can increase safety compliance, especially with regard to employees being more obedient to maintaining safety (safety compliance). The results of this study are in line with Vinodkumar and Bhasi, (2010) and Rosalita et al.

The results of testing the fourth hypothesis which states that workers involvement has a positive and significant effect on safety compliance with safety knowledge as mediation at PT Powerindo Prima Perkasa is supported. This is indicated by the p-value $0.018<0.05$ and the t-value $2.367 \geq 1.96$, which means that the research results show that workers involvement (X2) has an indirect and significant positive effect on employee safety compliance $(\mathrm{Y})$ mediated by safety. knowledge $(\mathrm{Z})$ at PT Powerindo Prima Perkasa.

The resulting path coefficient from $X 2$ to $Y$ is 0.340 with $p$ value $=0.000<0.05$. While the path coefficient mediated by $Z$ (safety knowledge) from $X 2 \rightarrow Z \rightarrow Y$ is 0.109 (positive) with a value of $p=0.018<0.05$. The resulting weight of the indirect effect is positive and significant, so it means that the presence of $Z$ (safety knowledge) causes the effect of $X 2$ (workers involvement) on $Y$ (safety compliance) to increase. Conversely, when without $Z$ (safety knowledge), the effect of $\mathrm{X} 2$ (workers involvement) on $\mathrm{Y}$ (safety compliance) decreases. This shows that $Z$ mediates $X 2$ against $Y$.

The results of this study support the research conducted by Aytac and Dursun (2018) which states that workers involvement has a strong and significant effect on safety compliance. In addition, Okoye et al., (2016) stated that worker involvement is a certain aspect of safety performance because knowledge and compliance alone are not enough to cause changes in safety performance behavior (safety compliance) but require certain aspects such as worker involvement. The results of this study are also supported by Chung (2018) who said that the most powerful intervention to improve employee safety compliance in organizations must be focused on safety knowledge. This is confirmed by research conducted by Neal et al.

\section{CONCLUSION}

Based on the research that has been done, followed by testing and analysis of the data obtained, this study provides a theoretical strengthening of the relationship between safety training, workers involvement and safety knowledge on safety compliance, which in previous studies this relationship is still being debated. So that this research can be used to generalize the findings of previous research. Based on the data analysis carried out in this study, the conclusions that can be presented from the results of this study are as follows: 1) Safety training directly has a positive effect on safety compliance. 2) Workers involvement directly has a positive effect on employee safety compliance. 3) Safety training indirectly has a positive effect on employee safety compliance through safety knowledge.

The suggestions for further research may be able to improve the limitations of this study by increasing the number of respondents, especially employees and by looking at including other variables that affect safety compliance, for example leadership, safety communication, safety motivation and others.

\section{REFERENCES}

1. Aytac, Sepril \& Dursun, Salih. (2018). "The Effect on the Safety Culture of Occupational Accidents and Safety Behavior: The Case of Turkey," Proceedings of International Academic Conferences 7809355, International Institute of Social and Economic Sciences. Retrieved from DOI: 10.20472 / IAC.2018.038.005.

2. Bunner, Johanna., Prem, Roman., Korunka, Christian. (2018). How Work Intensification Relates to Organization-Level Safety Performance: The Mediating Roles of Safety 
Climate, Safety Motivation, and Safety Knowledge. Journal Frontiers in Psychology. Volume 9. Retrieved from https://doi.org/10.3389/fpsyg.2018.02575.

3. Burke, MJ, \& Sarpy, SA (2003). Improving worker safety and health through interventions. In DA Hofmann \& LE Tetrick (Eds.). Health and safety in organizations (pp. 56-90). San Francisco: Jossey-Bass.

4. Christian, MS, Bradley, JC, Wallace, JC, \& Burke, MJ (2009). Workplace safety: A metaanalysis of the roles of person and situation factors. Journal of Applied Psychology, 94 (5), 1103-1127. Retrieved from https://www.icos.umich.edu/sites/default/files/lecturereadinglists/Christian\%20et\%20al\%2 02009\%20JAP.pdf.

5. Chung, Kyoung Su., (2018). Relationships between Safety Perception, Knowledge, and Compliance among Hospital Employees. Asia-pacific Journal of Convergent Research Interchange Vol. 4, No.4 December 31 (2018), pp. 71-80. Retrieved from http://dx.doi.org/10.14257/apjcri.2018.12.08.

6. Cooper, MD, Philips, RA, (2004). Exploratory analysis of the safety climate and safety behavior relationship. J. Saf. Res. 35 (5), 497-512. Retrieved from http://www.bsmsinc.com/articles/Exploratory_analysis_of_the_safety_climate_and_safety_behavior_relati onship.pdf.

7. Dahl, Oyvind (2013). safety compliance in a highly regulated environment; A case study of workers' knowledge of rules and procedures within the petroleum industry. Journal of safety science, 185-195. Retrieved from https://doi.org/10.1016/j.ssci.2013.07.020.

8. Elkind, PD (1993). Correspondence between knowledge, attitudes, and behavior in farm health and safety practices. Journal of Safety Research, 24, 171 - 179. Retrieved from https://doi.org/10.1016/0022-4375(93)90028-L.

9. Fabrigar, LR, Petty, RE, Smith, SM, \& Crites, SR (2006). Understanding knowledge effects on attitude-behavior consistency: The role of relevance, complexity, and amount of knowledge. Journal of Personality and Social Psychology, 90, 556-577. Retrieved from https://doi.org/10.1037/0022-3514.90.4.556.

10. Fibriany, Firstianty Wahyuhening., \& Oktaviani, Nur Hani. (2019). Evaluation of Employee Training Results on Employee Performance (Case Study of PT. Bank Bukopin). Journal of Ecodemica, Vol. 3 No. 2 September 2019. Retrieved from https://ejournal.bsi.ac.id/ejurnal/index.php/ecodemica/article/view/6140.

11. Goetsch, DL (2008). Occupational Safety and Health for Technologists, Engineers and Managers (6th ed.). New Jersey: Pearson Education Inc.

12. Guo, BHW, Yiu, TW, \& González, VA (2016). Predicting safety behavior in the construction industry: Development and test of an integrative model. Safety Science, 84, 1-11. Retrieved from https://doi.org/10.1016/j.ssci.2015.11.020.

13. Electronic Source: https://kemnaker.go.id/news/detail/menaker-jentuk-k3-sebagaiprioritas-dalam-berja.

14. Electronic Source: https://kemenperin.go.id/artikel/20128/Kemenperin-Beberkan-Data$\mathrm{Ke}]-$ Industri-Manufacturer-Nasional.

15. Huang, Y.-H., Verma, SK, Chang, W.-R., Courtney, TK, Lombardi, DA, Brennan, MJ, \& Perry, MJ (2012). Management commitment to safety vs. employee perceived safety training and association with future injury. Accident Analysis \& Prevention, 47, 94-101. Retrieved from https://doi.org/10.1016/j.aap.2011.12.001.

16. Jiang, L., Yu, G., Li, Y., \& Li, F. (2010). Perceived colleagues' safety knowledge / behavior and safety performance: Safety climate as a moderator in a multilevel study. Accident Analysis \& Prevention, 42 (5), 1468-1476. Retrieved from https://doi.org/10.1016/j.aap.2009.08.017.

17. Kao, K.-Y., Spitzmueller, C., Cigularov, K., \& Thomas, CL (2019). Linking safety knowledge to safety behaviors: a moderated mediation of supervisor and worker safety attitudes. European Journal of Work and Organizational Psychology, 1-15. Retrieved from https://doi.org/10.1080/1359432X.2019.1567492. 
18. Liu, Xinxia et al., (2015). Climate safety, safety behavior, and worker injuries in the Chinese manufacturing industry. Safety science 78 (2015) 173-178. Retrieved from https://doi.org/10.1016/j.ssci.2015.04.023.

19. Mashi, Munir Shehu et al (2016). The Effect of Safety Training and Workers Involvement on Healthcare Workers Safety Behavior: The Moderating Role of Consideration of Future Safety Consequences. International Journal of Business Management (IJBM). Vol. 1.

20. Masia, U., \& Pienaar, J. (2011). Unraveling safety compliance in the mining industry: examining the role of work stress, job insecurity, satisfaction and commitment as antecedents. SA Journal of Industrial Psychology, 37, 01-10. Retrieved from http://www.scielo.org.za/pdf/sajip/v37n1/v37n1a18.pdf.

21. Mearns, K., Flin, R., Gordon, R., \& Leming, M. (2001). Human and organizational factor in offshore safety. Work \& Stress, 15 (2), 144-160. Retrieved from https://doi.org/10.1080/026783701102678370110066616.

22. Neal, A. and Griffin, MA (2006), "A study of the lagged relationships among safety climate, safety motivation, safety behavior, and accidents at the individual and group levels", Journal of Applied Psychology, Vol. 91 No. 4, pp. 946-953. Retrieved from https://doi.org/10.1037/0021-9010.91.4.946.

23. Neal, A., Griffin, M., \& Hart, P. (2000). The impact of organizational climate on safety climate and individual behavior. Safety Science, 34 (1-3), 99-109. Retrieved from https://doi.org/10.1016/S0925-7535(00)00008-4.

24. Okoye, Peter Uchenna. Ezeokonkwo, John Ugochukwu. Fidelis Okechukwu Ezeokoli (2016). Building Construction Workers' Health and Safety Knowledge and Compliance on Site. Journal of Safety Engineering 2016, 5 (1): 17-26. Retrieved from DOI: 10.5923 / j.safety.20160501.03.

25. Pertiwi, Pujiani (2016). The Relationship Between Occupational Health and Safety Behavior (K3) and Occupational Accidents at Workers at PT Aneka Adhilogam Karya Ceper Klaten. Scientific Publications. Muhammadiyah Surakarta university. Retrieved from http://eprints.ums.ac.id/id/eprint/44301.

26. Rahab and Wahyuni. Purbudi (2013). Predicting Knowledge Sharing Intention Based on Theory of Reasoned Action Framework: An Empirical Study on Higher Education Institution. American International Journal of Contemporary Research. Vol. 3 No. 1. Retrieved from http://www.aijcrnet.com/journals/Vol_3_No_1_January_2013/16.pdf.

27. Rinehart, Erika K (2015). Effectiveness of Visual-Based Safety Training Compared with Non-Visual Based Safety Training in The Meat Processing Industry for Non-English Speaking, Hispanic Employees. Thesis.

28. Robbins and Judge. 2008. Organizational Behavior. Jakarta: Four Salemba.

29. Rosalita, Aditya Novi., Et al (2015). Mediating safety knowledge and safety motivation on the effect of safety management practices on the safety performance of employees in the production division of PT Petrokimia Gresik. Journal of Management Theory and Applied Year 8. No. 3, December 2015. Retrieved from http://dx.doi.org/10.20473/jmtt.v8i3.2737

30. Runyan, CW, \& Runyan, DK (1991). How can physicians get kids to wear bicycle helmets? A prototypic challenge in injury prevention. American Journal of Public Health, 81, 972 - 973.

31. Subramaniam, Chandarakanta. Faridahwati Mohd. Shamsudinb, Md. Typical Mohd. Zina, Subramaniam Sri Ramalub, Zuraida Hassana (2016). Safety Management Practices and Safety Compliance: A Model for SMEs in Malaysia. ISSC 2016: International Soft Science Conference. Retrieved from https://www.researchgate.net/

32. Sugiyono. (2015). Quantitative Research Methods, Qualitative, R \& D. Bandung.

33. Vinodkumar, MN and Bhasi, M. (2010). Safety Management Practices and Safety Behavior: Assessing the Mediating Role of Safety Knowledge and Motivation. Journal of Accident Analysis and Prevention 42 (2010) 2082-2093. Retrieved from https://doi.org/10.1016/j.aap.2010.06.021.

34. Vredenburgh G. A (2002). Organizational safety: Which management practices are most effective in reducing employee injury rate ?. Journal of Safety Research, 33, 259-276. Retrieved from https://doi.org/10.1016/S0022-4375(02)00016-6. 